\title{
PSYCHOLOGY OF RISK AND RETURN - PERSPECTIVES OF INDIAN WOMEN INVESTORS
}

\author{
Dr. Veena .M \\ Assistant Professor, VSK University, Ballari, Karnataka
}

Article DOI: https://doi.org/10.36713/epra5079

\begin{abstract}
- Women are increasingly seen as active agents of change, the dynamic promoters of social transformations that can alter lives of both women and men. - Amarty Sen (Renowned Economist from India).

The origin of the Indian idea of appropriate female Behaviour is described by Manu in 200 BC: as "by a young girl, by a young woman, or even by an aged one, nothing must be done independent, even in her own house". Their role typically restricted only for cooking, childcare, laundry, cleaning and the collection of water, fuel and wood. Women are continued to be excluded in social, economic and political domains.

In settings where socio cultural norms restrict women's mobility, their interactions with members of the opposite sex and their ability to attend trainings or receive formal education, women's access to information, institutions and markets is compromised. Despite this, major changes have occurred in the status of women in India.

Today's women are outpacing men in several areas and have high offices including that of the president, Prime Minister, Chief Ministers and Governors of the states. Surprisingly investing is one such area which still proves gender gap between men and women. However, few studies have been carried out on gender differences in investment behaviour and women investment behaviour, it was evidenced from those studies that women are more risk averse than men.

This study is an attempt to understand the psychology of Indian women towards Risk-Return characteristics of various investment avenues. For the purpose of study 480 Women investors have been surveyed and comprehensive view on their perspectives towards risk - return characteristics have been presented in this paper.
\end{abstract}

\section{INTRODUCTION}

The origin of the Indian idea of appropriate female Behaviour is described by Manu in 200 BC: as "by a young girl, by a young woman, or even by an aged one, nothing must be done independent, even in her own house". Their role typically restricted only for cooking, childcare, laundry, cleaning and the collection of water, fuel and wood. Women are continued to be excluded in social, economic and political domains.

21 st century and Indian women have come a really long way in terms of empowerment and leaving their signs in the country. The status of women in India has been subject to many great changes over the few millennia. Today's women are outpacing men in several areas and have high offices including that of the president, Prime Minister, Chief Ministers and Governors of the states. There are $42.8 \%$ women who earn equal to or more than their husbands.

Surprisingly investing is one such area which still proves gender gap between men and women. Because, still there are women outside with low confidence and believe they have less knowledge about finance than men when it comes to investing. Few literatures on women finance literacy evidenced women 
consistently score lower than men on measures of financial literacy, and this gender-based gap can negatively impact the financial well-being of women.

However, few studies have been carried out on gender differences in investment behaviour and women investment behaviour, it was evidenced from those studies that women are more risk averse than men and thus when it comes to investing they invest more conservatively and less in amounts than men, frequency of investment in female is lesser when compared to the male (Dr. Monica Sharma, 2013) ${ }^{43}$. Working women are conservative in nature. And they lack the knowledge needed to make proper decision about their finance (Juwairiya P P, 2014) ${ }^{44}$. Social norms, family responsibilities have negative impact on investment activities of women (Diana J Beal et. al., 2015) ${ }^{45}$.

But, it is important to note that the studies on gender differences in investing have been mostly concentrated on data from developed countries, especially from the U.S. And it is widely acknowledged that women in developed countries differ drastically in many aspects, such as beliefs, life styles, behaviours, habits, personal characteristics, etc. and it may be expected that investment attributes of women living in developed countries differ from investment attributes of women living in the emerging and developing country like INDIA, where the status of women is typical.

\section{BEHAVIOURAL BIASES}

Research in psychology has evidenced and documented a range of decision-making behaviours called biases. These biases can affect almost all types of decision-making, but have particular implications in relation to financial activities. These biases are related to how investors process information to reach decisions and the preferences they exhibit in the process of investment.

However, if we understand them and their effects, one may be able to reduce their influence and learn to work around them. The present study attempts to identify psychology of risk and return from the perspective of Indian Women Investors.

The following is the summary of key biases and their implications for investors, portfolio managers and advisors.

\section{Over Confidence}

Psychology has found that humans tend to have unwarranted confidence called as over confidence in their decision making. In essence, this means having an high view and overstatement of one's own abilities. This trait is universal, affecting most aspects of individual's lives.

\section{Self Attribution Bias}

Overconfidence may be fuelled by another characteristic known as 'self-attribution bias. In essence, this means that individuals faced with a positive outcome following a decision, will view that outcome as a reflection of their ability and skill. However, when faced with a negative outcome, this is attributed to bad luck or misfortune.

\section{Loss aversion - Attitudes to Risk and Reward}

Established financial theory focuses on the trade-off between risk and return. Risk from this perspective means variability of outcomes and riskier investments should, offer higher rates of return as compensation for higher risk.

Behavioral finance suggests investors are more sensitive to loss than to risk and return. Some estimates suggest investors weigh losses more than twice as heavily as potential gains. The idea of loss aversion also includes the finding that investors try to avoid locking into a loss.

\section{The Disposition Effect}

Professors Shefrin and Statman developed the idea of loss aversion into a theory called the 'disposition effect', which indicates that individuals tend to sell winners and hold losers. In later research, Professors Barber and Odean tested this idea using data from a retail brokerage. They found that the tendency to sell winners and hold losers harmed investment returns.

\section{Anchoring}

Anchoring describes how individuals tend to focus on recent information and give less weight to longer time periods. Anchoring indeed be a source of wrong decisions, as investors base their decisions on their reference groups. The only way of avoiding anchoring bias is rigorous critical thinking while making investment decisions, there is no substitute than this.

\section{Representativeness/Stereotyping}

The notion of 'representativeness' reflects the case where decisions are made based on a situation's superficial characteristics rather than a detailed evaluation of the reality. Another way of stating this would be saying that decisions are made based on stereotypes.

\section{Conservatism}

'Conservatism' describes the idea the decision maker clings to an initial judgment despite new contradictory information. Or they only partially adjust their view in light of the new information. Investors who buy shares in a high profile company may be slow 
to adjust their view of the company's prospects even after the company's profitability deteriorates.

These biases result in significant difference in the process of investment as stated in portfolio theories and Investment in practice.

\section{OBJECTIVE OF THE STUDY}

The present study intended

1. To identify the level of awareness of Indian Women Investors towards various Investment avenues
2. To understand the perception of Indian Women investors towards Risk and Return characteristics of various investment avenues.

This study presents the irrational perception of women towards various investment avenues.

\section{Sampling Design:}

For the purpose of achieving the objective 480 Women investors were surveyed using a structured questionnaire. Samples have been selected using convenient sampling method. Demographical profile and Socio-economic profile of the selected working women is presented in some other research papers of the researcher (References 14, 15 and 16).

DATA ANALYSIS AND DISCUSSION OF RESULTS

Table 1 - Showing Respondents Awareness about availability of Varieties of Investment Avenues

\begin{tabular}{|c|l|c|c|c|c|}
\hline \multirow{2}{*}{ SL.NO. } & \multirow{2}{*}{ Are you aware of following Investment Avenue? } & \multicolumn{2}{|c|}{ Yes } & \multicolumn{2}{c|}{ No } \\
\cline { 3 - 5 } & & Frequency & $\mathbf{\%}$ & Frequency & \% \\
\hline 1 & Bank deposits & 478 & 99.60 & 2 & 0.40 \\
\hline 2 & Post office deposits and savings & 362 & 75.40 & 118 & 24.60 \\
\hline 3 & Insurance & 348 & 72.50 & 132 & 27.50 \\
\hline 4 & Real estates & 122 & 25.40 & 358 & 74.60 \\
\hline 5 & Mutual funds & 190 & 39.60 & 290 & 60.40 \\
\hline 6 & Equity and stock market instruments & 40 & 8.30 & 440 & 91.70 \\
\hline 7 & Money market instruments(CD's, CP,s \& notes) & 30 & 6.30 & 450 & 93.80 \\
\hline 8 & Derivative instruments (options, Futures) & 32 & 6.70 & 448 & 93.30 \\
\hline 9 & Government securities & 220 & 45.80 & 260 & 54.20 \\
\hline 10 & Bonds and Debentures & 142 & 29.60 & 338 & 70.40 \\
\hline 11 & Gold/Silver/other metals & 258 & 53.80 & 222 & 46.30 \\
\hline
\end{tabular}

Source: Field Survey

Remarks: The total numbers of responses are not equal to 480 since a single respondent may be aware of more than one avenue listed in the table and hence can opt for more than one response.

The contents of the above table numbered 5.3 are self explanatory relating to the awareness level of respondents with regard to different investment avenues available in the market. However few figures of the table have explained. Around $99.60 \%$ of respondents were aware of Bank deposits. Nearly 72 to $75 \%$ of respondents were aware of insurance and post office deposits. $45.80 \%$ and $39.60 \%$ of respondents were aware of Government Bonds and Mutual funds. And very negligible percentages of respondents were aware of money market instruments, derivatives and equity stocks. Bank deposits, Insurance schemes and Post office deposits are the most popular investment avenues among selected working women. 


\section{SJIF Impact Factor: 7.001| ISI I.F.Value:1.241| Journal DOI: 10.36713/epra2016 ISSN: 2455-7838(Online) EPRA International Journal of Research and Development (IJRD) Volume: 5 | Issue: 9 | September 2020

Frequency Distribution of responses against the Risk associated with Investment Avenues

\begin{tabular}{|c|l|c|c|c|c|c|}
\hline SL.NO. & \multicolumn{1}{|c|}{ Risk Associated with Avenues (\%) } & VH & $\mathbf{H}$ & $\mathbf{M}$ & $\mathbf{L}$ & $\mathbf{V L}$ \\
\hline 1 & Bank deposits & 23.3 & 16.3 & 21.7 & 27.9 & 10.8 \\
\hline 2 & Post office deposits and savings & 15.0 & 23.3 & 12.5 & 43.3 & 5.8 \\
\hline 3 & Insurance & 7.1 & 14.6 & 45.4 & 30.4 & 2.5 \\
\hline 4 & Real estates & 37.5 & 9.2 & 18.8 & 26.3 & 8.3 \\
\hline 5 & Mutual funds & 24.6 & 11.7 & 42.5 & 12.1 & 8.3 \\
\hline 6 & Equity and stock market instruments & 26.3 & 6.7 & 42.5 & 13.3 & 11.3 \\
\hline 7 & Money market instruments(CD's, CP,s \& notes) & 25.8 & 9.6 & 35.4 & 18.3 & 10.8 \\
\hline 8 & Derivative instruments (options, Futures) & 18.8 & 10.0 & 45.0 & 15.4 & 10.8 \\
\hline 9 & Government securities & 14.2 & 13.8 & 18.8 & 37.1 & 16.3 \\
\hline 10 & Bonds and Debentures & 20.8 & 14.6 & 27.5 & 27.1 & 10.0 \\
\hline 11 & Gold/Silver/other metals & 18.3 & 15.4 & 31.3 & 25.4 & 9.6 \\
\hline
\end{tabular}

( $\mathbf{V H}=$ Very High, $\mathbf{H}=$ High, $\mathbf{M}=$ Moderate, $\mathbf{L}=$ Less, $\mathbf{V L}=$ Very Less)

Table no. 5.11 depicts risk perception of respondents towards different investment avenues. The figures given in the table above are self explanatory. However few significant figures are described as follows.

Bank Deposits: $29.7 \%$ and $16.3 \%$ of respondents opined that bank deposits are less risky and very less risky avenue. Put together $46 \%$ of respondents opined that bank deposits are good avenues to invest to those who don't want to take risk. And $21.7 \%$ opined bank deposits are medium risk assets. Another, $23.3 \%$ and $10.8 \%$ (totally $34.1 \%$ ) opined bank deposits are risky assets since investment in private banks are risky.

Post office Savings and Deposits: Majority i.e., $43.3 \%$ and $5.8 \%$ (totally $49.1 \%$ ) opined post office deposits are less and very less risky respectively. Whereas, $15 \%$ and $12.5 \%$ of respondents (sum totally $27 \%$ ) opined post office savings and deposits carry very high and high risks respectively.

Insurance: according to $45.4 \%$ of respondents insurance carry medium risk. The respondents opined the risk in relation with hedging.

Real estate: $37.9 \%$ and $9.2 \%$ (totally $47.1 \%$ ) opined investment in real estates involves high and very high risk.

Mutual Funds: according to $42.5 \%$ of respondent's Mutual funds carry medium risk. And another 24.6\% and $11.7 \%$ ( totally $36.3 \%$ ) opined investment in Mutual funds involves very high and high risk respectively.

Equity and stock market instruments: around $42.5 \%$ opined Equity stocks carry medium risk and another $26.3 \%$ and $9.6 \%$ (totally 35.9 ) of respondents opined equity stocks are highly risk assets.

Money market instruments: around $25.8 \%$ and $9.6 \%$ (totally $35 . \%$ ) of respondents found money market instruments as high risk and risky avenues respectively and another $35.4 \%$ found them as medium risk carrying avenues.

Derivatives: Majority i.e., $45 \%$ of respondents' opined derivatives carry medium risk and another $18.8 \%$ and $10 \%$ put together $28.8 \%$ opined that derivatives carry high risk.

Government securities: Good number of respondents i.e., 37.1 and $16.3 \%$ (totally $53.4 \%$ ) agreed that the government securities are less risky and very less risk avenues respectively.

Debentures: Researcher found mixed opinions in this case. According to $27.5 \%$ of respondents debentures attract medium risk. And another $27.1 \%$ opined that these are less risky avenue. And another 10\% agreed that these are highly less risky avenues.

Gold/silver/other metals: According to $31.3 \%$ of respondents' investment in these avenues carry medium risk and another $25.4 \%$ and $9.6 \%$ of respondents opined that these avenues are less risky and highly less risky assets respectively.

As per the survey results Bank deposits, post office deposits, Insurance and Government securities were considered as risk free assets for investment, while, investment in mutual funds, derivatives, debentures, gold/silver and other metals carry medium risk. On the other hand investment in money market instruments and real estates were considered as high risk carrying instrument by the selected working women. 
SJIF Impact Factor: 7.001| ISI I.F.Value:1.241| Journal DOI: 10.36713/epra2016 ISSN: 2455-7838(Online) EPRA International Journal of Research and Development (IJRD)

Volume: 5 | Issue: 9 | September 2020

- Peer Reviewed Journal

Frequency Distribution of responses against the Return associated with Investment Avenues

\begin{tabular}{|c|l|c|c|c|c|c|}
\hline SL.NO. & \multicolumn{1}{|c|}{ Return Associated with Avenues (\%) } & $\mathbf{V H}$ & $\mathbf{H}$ & $\mathbf{M}$ & $\mathbf{L}$ & $\mathbf{V L}$ \\
\hline 1 & Bank deposits & 6.7 & 21.7 & 20.0 & 22.9 & 28.8 \\
\hline 2 & Post office deposits and savings & 5.4 & 32.1 & 16.7 & 15.4 & 30.4 \\
\hline 3 & Insurance & 6.3 & 25.0 & 36.3 & 21.3 & 11.3 \\
\hline 4 & Real estates & 24.2 & 34.2 & 27.5 & 11.3 & 2.9 \\
\hline 5 & Mutual funds & 19.6 & 32.9 & 20.8 & 25.4 & 1.3 \\
\hline 6 & Equity and stock market instruments & 23.8 & 12.1 & 17.5 & 40.4 & 6.3 \\
\hline 7 & Money market instruments(CD's, CP,s \& notes) & 22.5 & 11.7 & 34.6 & 25.0 & 6.3 \\
\hline 8 & Derivative instruments (options, Futures) & 20.8 & 12.1 & 29.6 & 31.3 & 6.3 \\
\hline 9 & Government securities & 9.6 & 11.3 & 40.8 & 28.3 & 10.0 \\
\hline 10 & Debentures & 17.1 & 16.7 & 32.9 & 26.7 & 6.7 \\
\hline 11 & Gold/Silver/other metals & 17.5 & 28.8 & 25.0 & 25.0 & 3.8 \\
\hline
\end{tabular}

Source: Field Survey

(VH= Very High, $\mathbf{H}=$ High, $\mathbf{M}=$ Moderate, $\mathbf{L}=$ Less, $\mathbf{V L}=$ Very Less)

Table no. 5.12 betrays perception of working women about returns associated with different investment avenues. The figures given in the table above are self explanatory. However a few significant figures are used to describe the data.

Bank Deposits: Around 28.8\% and 22.9\% (totally $51.7 \%$ ) of respondents opined that bank deposits earn very less and less return respectively.

Post office Savings and Deposits: The researcher found mixed opinions in this case. As explained in the table around $32.1 \%$ perceived that post office savings and deposits attract good returns whereas another $30.4 \%$ opined that these avenues earn very less rate of returns.

Insurance: Around $36.3 \%$ of respondents opined that insurance earns medium returns.

Real estate: $34.2 \%$ and $24.2 \%$ (totally $58.4 \%$ ) opined that real estate earns high and very high rate of returns respectively. Another $27.5 \%$ of the respondents opined that real estate earn medium rate of return

Mutual Funds: According to $32.9 \%$ and $19.6 \%$ (totally 52.5\%)of respondent's Mutual funds carry high and very high return. And another $20.8 \%$ and $25.4 \%$ opined that Mutual earn medium and less returns respectively.

Equity and stock market instruments: Majority i.e., $40.4 \%$ of respondents perceived that equity stock earns lower rates of returns. Another $23.8 \%$ and $12.1 \%$ of respondents' opined equity stock earns very high and high rate of returns respectively.

Money market instruments: $34.6 \%$ and $25 \%$ of respondents opined that money market instruments earn medium and lower rates of returns. And another 22.5\% and $11.7 \%$ (totally 34.2 ) of respondents are aware that money market instruments earn very high and high rate of returns.

Derivatives: $3 \quad .1 \%$ conceived that derivatives earn less. Another 29.6\% said derivatives are medium earning instruments and 20.8 and $12.1 \%$ (totally $32.9 \%$ ) of respondents opined that they earn high and very high returns respectively.

Government securities: Good number of respondents i.e., $40.8 \%$ opined government securities carry medium rate of return. Another $28.3 \%$ respondents perceived that these avenues earn less rate of return.

Debentures: $32.9 \%$ and $26.7 \%$ of respondents' opined debentures earn medium and less rate of return respectively.

Gold/silver/other metals: Researcher found mixed results even in this case $28.8 \%$ and $17.5 \%$ of respondents opined that these avenues earn high and very high returns, another $25 \%$ said that they earn medium returns whereas, another $25 \%$ of respondents opined that they earn less rate of return.

As per survey results Bank deposits, post office deposits, insurance, derivatives investment in gold/silver and other metals yield less rate of returns. Investment in debentures, government securities were considered as moderately yielding avenues. Wherein, Investment in money market instruments, mutual funds and real estates were considered as highly yielding investment avenues by the selected working women. 


\section{EPRA International Journal of Research and Development (IJRD)}

Volume: 5 | Issue: 9 | September 2020

- Peer Reviewed Journal

\section{MULTI CRITERIA DECISION ANALYSIS (RANK ORDERING) OF DATA BASED ON WEIGHTED MEAN VALUES (WMV)}

Ranking of level of Awareness towards various Investment Avenues by the selected Working Women

\begin{tabular}{|c|l|c|c|}
\hline SL.NO. & \multicolumn{1}{|c|}{ Awareness towards } & WMV & Ranks \\
\hline 1 & Bank deposits & 1 & I \\
\hline 2 & Post office deposits and savings & 0.75 & II \\
\hline 3 & Insurance & 0.73 & III \\
\hline 4 & Real estates & 0.25 & VIII \\
\hline 5 & Mutual funds & 0.4 & VI \\
\hline 6 & Equity and stock market instruments & 0.08 & IX \\
\hline 7 & Money market instruments(CD's, CP,s \& notes) & 0.06 & XI \\
\hline 8 & Derivative instruments (options, Futures) & 0.07 & X \\
\hline 9 & Government securities & 0.46 & V \\
\hline 10 & Bonds and Debentures & 0.3 & VII \\
\hline 11 & Gold/Silver/other metals & 0.54 & IV \\
\hline
\end{tabular}

Source: Field Survey

The above table depicts the ranking of investment avenues from most popular to least popular among working women. The table is self explanatory however, a few significant figures are explained. Bank deposit was ranked as top I popular avenues, by the working women. Post office deposits and insurance were ranked as II and III popular avenues respectively. Gold/silver/other materials, Government Securities and Mutual funds were the next popular avenues with ranks of IV, V and VI respectively. Money market instruments were the last popular avenue among working women.

\section{Ranking of Risk perception towards investment avenues by the selected Working Women (from low} to high)

\begin{tabular}{|c|l|c|c|}
\hline SL.NO. & \multicolumn{1}{|c|}{ Risk Associated with } & WMV & Rank \\
\hline 1 & Bank deposits & 2.73 & IX \\
\hline 2 & Post office deposits and savings & 3.02 & III \\
\hline 3 & Insurance & 3.07 & II \\
\hline 4 & Real estates & 2.59 & XI \\
\hline 5 & Mutual funds & 2.68 & X \\
\hline 6 & Equity and stock market instruments & 2.77 & VIII \\
\hline 7 & Money market instruments(CD's, CP,s \& notes) & 2.79 & VII \\
\hline 8 & Derivative instruments (options, Futures) & 2.9 & VI \\
\hline 9 & Government securities & 3.27 & I \\
\hline 10 & Bonds and Debentures & 2.91 & V \\
\hline 11 & Gold/Silver/other metals & 2.92 & IV \\
\hline
\end{tabular}

Source: Field Survey

The above table depicts the risk perception towards various investment avenues. As per the figures government securities were regarded as least risky asset among all other avenues (ranked as I). Insurance was ranked as the second avenue with less risk character. Insurance and gold/silver/other materials were regarded as III and IV less risky assets. Real estate considered as the most risky asset as per the ranks order of II. 
Correlation between Psychological factors and Investment Preference

\begin{tabular}{|c|c|c|c|c|c|c|c|c|c|c|c|}
\hline \multirow{2}{*}{$\begin{array}{l}\text { Psychological } \\
\text { factors (IV) }\end{array}$} & \multicolumn{11}{|c|}{ Investment preference (DV) } \\
\hline & BD & POD & IS & $\mathbf{R E}$ & MF & ES & MMI & DI & GS & Deb. & $\begin{array}{c}\text { G/S/O } \\
\text { M }\end{array}$ \\
\hline Confidence Level & & $\begin{array}{l}- \\
.102 * \\
*\end{array}$ & & & $\begin{array}{l}.025^{*} \\
*\end{array}$ & & & $\begin{array}{l}.018 \\
* *\end{array}$ & & & $.167^{* *}$ \\
\hline Investor Optimism & $\begin{array}{l}- \\
.103^{*} \\
*\end{array}$ & & $\begin{array}{l}- \\
.027^{*} \\
*\end{array}$ & $\begin{array}{l}.212 \\
* *\end{array}$ & & $\begin{array}{l}.066 \\
* *\end{array}$ & $\begin{array}{l}.126 \\
* *\end{array}$ & & $\begin{array}{l}.145^{*} \\
*\end{array}$ & $\begin{array}{l}.077 \\
* *\end{array}$ & \\
\hline Conservatism & & $\begin{array}{l}- \\
.209 * \\
*\end{array}$ & & & $\begin{array}{l}-\overline{-} \\
.047^{*} \\
*\end{array}$ & & & $\begin{array}{l}.038 \\
* *\end{array}$ & & & $\begin{array}{l}- \\
.071^{* *}\end{array}$ \\
\hline Investor Beliefs & & $\begin{array}{l}.090^{*} \\
*\end{array}$ & $\begin{array}{l}.027^{*} \\
*\end{array}$ & & & & & $\begin{array}{l}.078 \\
* *\end{array}$ & $\begin{array}{l}- \\
.101 * \\
*\end{array}$ & & $.154^{* *}$ \\
\hline
\end{tabular}

Remarks: **. Correlation is significant at the 0.01 level ( 2 tailed)

*. Correlation is significant at the 0.05 level (2 tailed)

(BD-Bank Deposits, POD-Post Office Deposits, IS- Insurance, RE-Real Estate, ES-Equity Shares, MMI- Money Market Instruments, DI- Derivatives, GS-Government Securities, Deb. Debentures, G/S/OM - Gold/Silver/Other Metals)

The table above reveals the correlation between psychological factors and investment preference by the investors. The figures above reveal the strong correlation between investors' Psychological factors and investment preference by the investors. The highest positive correlation exists between investors' beliefs and preference towards investment in mutual funds as indicated by the ' $r$ ' value .733 . The next highest, negative correlation is identified with investors' beliefs and investment preference towards equity shares as evidenced by the ' $r$ ' value of -.428 . The $r$ value of -.369 signals the negative correlation between investor beliefs and investor preference towards investment in real estate. Investor optimism is directly correlated by the $r$ value of .273 with that of investment preference towards derivatives. The $r$ values of .220 and .212 indicate the positive correlation between confidence level and investment preference towards insurance and investor optimism and investment preference towards real estate's respectively. As witnessed by the figures Investors' beliefs play vital role in investment decision making. Selected working women who are not optimistic have negative opinion towards investment in real estates and equity instruments as the level of risk involved in these avenues is high. Optimistic investors also prefer to invest in avenues yielding capital appreciation and good returns like real estates and mutual funds.

\section{SUMMARY OF FINDINGS AND CONCLUSION}

The selected Working women perceived that they have average knowledge towards availability of various investment avenues and stock market mechanism. But it is observed that working women know less than an average investor towards the availability of various investment avenues and stock market mechanism.

The choice of investment avenues depends on the perception towards risk and return associated with the investment avenues by the working women. Investment in real estates and equity and money market instruments are considered as the most risky avenues by the investors. Investment in Insurance and post office deposits are considered as less risky assets by the working women. Whereas derivatives, debentures and mutual funds are regarded as moderate risky assets.

Return on the asset is another factor influencing investment decision by the working women. Bank deposits, post office deposits and insurance are considered as less yielding avenues, derivatives and debentures are considered as moderately yielding avenues whereas, real estates, mutual funds and equities \& money market instruments are considered as high yielding revenues among the available avenues by the working women.

Psychological factors of the working women highly correlated with the choice of Investment Avenue and the preference towards investment avenues. 


\section{SJIF Impact Factor: 7.001| ISI I.F.Value:1.241| Journal DOI: 10.36713/epra2016 ISSN: 2455-7838(Online) EPRA International Journal of Research and Development (IJRD) Volume: 5 | Issue: 9 | September 2020 \\ - Peer Reviewed Journal}

Psychological factors have negatively correlated with investment preference towards avenues carrying high level of risk like real estates and money market instruments and positively correlated with preference towards investment in mutual funds.

Investor's optimism positively correlated with investment in stock market instruments, long term avenues and avenues yielding capital appreciation. And optimism negatively correlated with investment in post office and government securities. Working women's optimism and confidence level have the highest correlation with investment objectives of the working women.

Investor's beliefs have significant correlation with the choice of investment avenues by the working women. Where investor beliefs has negative influence on investment in debentures, derivatives and money market instruments.

Conservatism has high correlation with the choice of investment avenues and objectives of investment by the working women. Whereas, conservatism positively correlated with investment in bank deposits, post office deposits and insurance. Conservatism positively correlated with the objectives of liquidity and marketability of their avenues by the working women.

\section{CONCLUSION}

Study on Investment Behaviour is a hot cake within the academic community. Behavioural finance is relatively a new area of study, which ramified from rational behaviour in investing. Many research studies have been conducted in developed countries have proved that there is great impact of Risk perception on the investment decision of investors in general. Few studies on gender difference in investment decisions evidenced that women are significantly different than men in making investment decisions. And it is widely acknowledged that women in developed countries differ drastically in many aspects, such as beliefs, life styles, behaviours, habits, personal characteristics, etc. and it may be expected that investment attributes of women living in developed countries differ from investment attributes of women living in these emerging and developing countries like India, where the status of women is typical. The study attempted to identify the level of awareness and perception of Indian Women Investors towards various Investment Avenues. The Study found the significant variation in the perception and the actual risk -return characteristics of the avenues; this is due to lack of financial literacy and participation in investing activities.
Hence it is suggested to the financial service providing institutions to conduct continues and effective investor education programmes to enhance the level of awareness of Women towards the nature of various investment avenues and should conduct continuous behavioral studies to devise appropriate strategies to bring the women investing community to the main stream.

\section{REFERENCES}

1. Alistair Byrne, "Behavioural finance - theories and evidences" , CFA Institute and Research Foundation, Maike Brooks and CO.

2. Awais, M., Laber, F., Rasheed, N. \& Khursheed, A (2016). "Impact of Financial Literacy And Investment Experience on Risk Tolerance And Investment Decisions: Empirical Evidence From Pakistan" International Journal of Economics And Financial Issues, 6(1), 73-79.

3. Baba Shiv, G. L. "Investment Behaviour and the Negative Side of Emotion” American Psychological Society , 16, 435- 439

4. Brad $M$ Barber And Terrance Odean, "The Behaviour of Individual Investors" Http://Ssrn.Com/Abstract $=1872211$

5. Cohn, Richard A., Wilbur G. Lewellen, Ronald C. Lease \& Gary G. Schlarbaum, "Individual Investor Risk Aversion And Investment Portfolio Composition", Journal of Finance

6. Dr. Gagan Kukreja (Dec. 2012), "Investors Perception for Stock Market- Evidences from National Capital Region of India", Interdisciplinary Journal of Contemporary Research in Business, Vol. 4, No.8

7. Dr. Mandeep Kaur and Tina Vohra ((December 2012), "Understanding Individual Investors Behaviour- A Review of Empirical Evidences", Pacific Business Review International, Vol. 5, Issue 6

8. Dr. Monica Sharma And Dr. Vani Vasakarla (July 2013), “ An Empirical Study of Gender Differences in Risk Aversion and Overconfidence in Investment Decision Making", International Journal of Application or Innovation in Engineering \& Management (IJAIEM), Vol. 2, Issue 7

9. Dr. R Sellappan and Jamuna "Investment Attitude of Women towards Different Sources of SecuritiesA Factor Analysis Approach", Global Journal Management And Business Research Finance, Vol. 13 Issue 3

10. Dr. Sindhu K P And Dr. Rajitha Kumar (June 2014), "Influence of Risk Perception of Investors on Investment Decisions - An Empirical Analysis", Journal of Finance and Bank Management, Vol. 2, No. 2, PP 15-25

11. Gert Abraham Lowies, John Henry Hall and Christian Ernst Cloete (2012), "The Role of 


\section{EPRA International Journal of Research and Development (IJRD)}

Volume: 5 | Issue: 9 | September 2020

Behavioural Aspects in Investment Decision Making By Listed Property Fund Managers in South Africa", Master Thesis, University Pretoria

12. Lubna Riaz and Ahmed Imran Hunjra (2012), "Impact of Psychological Factors on Investment Decision Making Mediating By Risk Perception - A Conceptual Study", Middle East Journal of Scientific Research, PP 789-795

13. Selim Aren and Sibel Dinc, "Behavioural Biases on Institutional Investors", Emerald Insight, Information and Knowledge Management, Vol. 45, Issue 10

14. Dr. Veena M and Prof. Ramesh O. Olekar "Impact of Demographical Factors on Investment Behaviour of Working Women - A Case Study of Hyderabad Karnataka Region" in International Journal of Management Science and Technology", Volume 9, Issue 3, ISSN - 2250 1959, Page 217 238, March 2018

15. Dr. Veena $M$, "Investment Profile of Working Women of Hyderabad Karnataka Region" EPRA International Journal of Economic and Business Review-Online ISSN 2347-9671 \& Print ISSN 2349-0187, Volume 7, Issue 2, $17^{\text {th }}$ February 2019

16. Dr. Veena $M$ "Influence of Behavioural Biases on Investment Behaviour of Women - Investors - A study on Hyderabad Karnataka Region", Studies in Indian Place Names, ISSN: 2394-3114, Vol-40, Issue 1, January 2020

17. Zipporah Nyaboke Onsomu (Jun 2014), “The Impact of Behavioral Biases On Investor Decisions In Kenya: Male Vs Female”, International Journal of Research in Humanities, Arts and Literature, Vol. 2, Issue 6, 87-92. 